\title{
PROBLEMS RELATED TO THE REGISTRATION IN WESTERN CANADA OF FOREIGN LIMITED PARTNERSHIPS AND THE OWNERSHIP BY SUCH PARTNERSHIPS OF INTERESTS IN OIL AND GAS LEASES ISSUED PURSUANT TO SECTION 55 OF THE CANADA OIL AND GAS LAND REGULATIONS
}

\author{
JOHN H. W. RATHWELL*
}

\begin{abstract}
This article analyzes the practical problems of the drilling fund-which is becoming an increasingly common method of obtaining financing for the exploration and production of oil and gas. The article discusses whether or not it is necessary to register a limited partnership drilling fund formed in the United States under the legislation of Canadian oil and gas jurisdictions, the ability of such a limited partnership to carry on business in these jurisdictions without jeopardizing the limited liability of its limited partners, the number of members that the drilling fund partnerships may have and the name that it may use under the said legislation. The article also considers whether or not a drilling fund qualifies under Section 55 of the Canada Oil and Gas Land Regulations.
\end{abstract}

\section{A. INTRODUCTION}

The expression "drilling fund" is one that is becoming increasingly commonplace in the oil and gas industry as a general description of an organization, formed by an oil and gas operator, which raises funds for use in drilling and exploration through the sale to the public of interests in limited partnerships formed for the purpose of engaging in the oil and gas business. To date, because of the income tax advantages which are available to United States citizens who participate in the oil and gas industry, the formation of public drilling funds, to the writer's knowledge, has been confined to the United States. However, a number of the drilling funds formed in the United States participate in the oil and gas business in Canada, and it is the purpose of this paper to consider some of the problems related to the registration of such limited partnerships in the Provinces of Alberta, British Columbia and Saskatchewan, and in the Yukon Territory and the Northwest Territories, and also to consider the ability of such limited partnerships to own interests in oil and gas leases issued pursuant to Section 55 of the Canada Oil and Gas Land Regulations. ${ }^{1}$

\section{B. REGISTRATION OF DRILLING FUND PARTNERSHIPS}

The first question to be considered is whether, under the laws of Alberta, British Columbia, Saskatchewan, the Yukon Territory and the Northwest Territories, it is necessary to register a limited partnership formed outside of such jurisdictions (hereinafter sometimes referred to as "the jurisdictions"). In this regard, Section 48 of the Partnership Act of British Columbia provides as follows: ${ }^{2}$

Limited partnerships for the transacting of any trading, manufacturing, or mining business within the province may be formed by two or more persons upon the terms, with the rights and powers, and subject to the conditions and liabilities hereinafter

* Barrister and Solicitor, Saucier, Jones, Black, Gain, Stratton and Laycraft, Calgary, Alberta.

' Canada Oil and Gas Land Regulations, SOR/61-253, (1961) 95 Canada Gazette (Part I1) 805, 6 June, 1961.

2 Partnership Act, R.S.B.C. 1960, c.277, as amended. 
mentioned; but the provisions of this Part do not authorize any such partnership for the purpose of banking, or the construction or working of railways or making insurance. [Emphasis added.]

It will be noted that the above quoted section states that a limited partnership may be formed by two or more persons. The limited partnership provisions of the partnership legislation of Alberta, ${ }^{3}$ Saskatchewan, ${ }^{4}$ the Yukon Territory ${ }^{5}$ and the Northwest Territories ${ }^{6}$ are identical in this respect.

After stating that a limited partnership may be formed, the legislation of each of the jurisdictions goes on to provide, among other things, the requirements which must be met in order to validly create a limited partnership. Such legislation does not contain any provision for the registration of limited partnerships formed outside the jurisdiction. It is the writer's opinion that since the partnership legislation of each of the jurisdictions speaks only of limited partnerships formed in the jurisdiction, a drilling fund partnership formed outside the jurisdiction would not be subject to the limited partnership provisions of such legislation, including the registration requirements.

\section{RECOGNITION OF STATUS AND RIGHT OF DRILLING FUND PARTNERSHIPS TO CARRY ON BUSINESS}

Since the limited partnership legislation of each of the jurisdictions does not make provision for the registration of foreign limited partnerships, the question is raised as to whether such foreign limited partnerships are even entitled to carry on business in the jurisdiction. In this regard, it is a well established principle of law that in the absence of legislation to the contrary, the creation, continued existence and capacity of a company to carry on business in a foreign jurisdiction is determined by the laws of the place of incorporation. ${ }^{7}$ Does such principle also extend to the recognition of the status of a foreign limited partnership? The judgment of Mr. Justice Riddell in the case of Henderson v. Strang in the Ontario Appellate Division would indicate that such principle does extend to the recognition of a foreign partnership which is considered to be a separate legal entity under the laws of the jurisdiction where it was formed. In the Henderson case, the question was raised as to whether a partnership formed in Scotland, which was a separate legal entity according to the laws of Scotland, would be recognized as a separate entity in Ontario. In this connection, Mr. Justice Riddell stated: 9

Moreover, the firm is not the shareholder. We need not consider what the legal status of a partnership and its members might be in the absence of a statute. The Imperial Act, 1890, 53 \& 54 Vict. ch. 39, sec. 4(2), expressly enacts: "In Scotland a firm is a legal person distinct from the partners of whom it is composed." ... The status of a partnership in Scotland determines its status in Ontario.

The case was appealed to the Supreme Court of Canada, ${ }^{10}$ and while

\footnotetext{
The Partnership Act, R.S.A. 1970, c.271.

4 The Partnership Act, R.S.S. 1966, c.387, as amended.

s The Partnership Ordinance, R.O. Yuk., 1958, c.84.

- The Partnership Ordinance, R.O.N.W.T., 1965, c.75, as amended.

7 Stiftung v. Rayner [1966] A.C. 583 (H.L.) and National Trust Co. Ltd. v. Ebro Irrigation [1954] O.R. 464.

- (1919) 45 O.L.R. 215.

- Id. at 223.

10 (1920) 60 S.C.R. 201.
} 
the question as to the legal status of the partnership formed in Scotland was not considered in the majority judgment of the court, $\mathrm{Mr}$. Justice Mignault ${ }^{11}$ specifically stated that the law of Scotland determined the legal status of the partnership and that according to such law the partnership was a separate legal entity. Mr. Justice Anglin, whose judgment was concurred in by Brodeur $J$., approved of the judgment of $\mathrm{Mr}$. Justice Riddell in the Ontario Court of Appeal which, as indicated above, dealt specifically with the point.

It would, therefore, appear that a drilling fund partnership would be recognized in each of the jurisdictions if such a partnership was considered to be a separate legal entity according to the laws of the jurisdiction where it was formed. ${ }^{12}$ In this regard, it is the writer's understanding that most of the states of the United States have adopted the provisions of The Uniform Limited Partnership Act, and although such Act does not specifically provide that a limited partnership is a separate legal entity, it has been interpreted to the effect that limited partnerships formed pursuant thereto are considered to be separate legal entities for some purposes. Whether such a limited partnership would be considered to be a separate legal entity in determining its capacity to carry on business in a foreign jurisdiction is not clear. However, it would seem that there is no particular reason why a foreign limited partnership, whether it is a separate legal entity or not, should not be recognized. Each individual member of the partnership would be recognized as being entitled to carry on business in each jurisdiction, and if the partnership is not a separate entity, it simply would be a matter of recognizing each of the individuals as carrying on business in Canada through a partnership with other individuals who are also entitled as individuals to carry on business in Canada. It cannot be disputed that some form of organization has been created outside the jurisdiction and that the laws of the place of formation confer certain rights, duties and obligations on the members of that organization, including limited liability. It is the writer's view that the courts should not be overly technical in their approach to this matter but, rather, should take a more practical and realistic approach which would lead to recognition of the right of a foreign limited partnership to carry on business in the jurisdiction notwithstanding that, strictly speaking, it may not be a separate legal entity.

If it should be determined that a drilling fund partnership would be recognized in each jurisdiction, there remains the further question as to whether that recognition would include recognition for the purpose of allowing it to carry on business in each jurisdiction without jeopardizing the limited liability of the limited partners.

In the case of Bateman v. Service, ${ }^{13}$ a company incorporated under the State of Victoria, Australia, had carried on business in the State of Western Australia without complying with the requirements of the Joint Stock Companies Ordinance Act, 1858, of Western Australia. That Ordinance provided for the formation of companies in Western Australia and set forth various requirements that had to be met in order to form a company under the Ordinance. The Ordinance did not contain provisions relating to the registration of companies formed out-

11 Id. at 213.

12 The United States cases of Silberman v. Blodgett (1926) 134 A. 778 and Gilman Paint \& Varnish Co. v. Legun (1950) 80 A. $2 d 906$ support this proposition.

13 (1881) 6 A.C. 386 (P.C.). 
side of Western Australia, and the question at issue in the case was whether the company incorporated under the laws of Victoria was required to comply with the Joint Stock Companies Ordinance Act, 1858, of Western Australia, and whether its failure to do so subjected its shareholders to liability for the company's debts and engagements incurred in Western Australia. The Privy Council held that, based on the principle of comity of nations, the Victorian company was entitled to carry on business in Western Australia unless there was some statutory provision which prohibited it from so doing. It was held that the Western Australian Joint Stock Companies Ordinance Act, 1858, did not purport to apply to companies incorporated outside of Western Australia, and that the liability of the shareholders of the company for the debts and obligations of the company incurred in Western Australia was to be determined in accordance with the laws where the company was incorporated. Sir Richard Couch stated: ${ }^{14}$

In the argument for the Appellant it was conceded that the general principle was, as stated by Mr. Justice Lindley in his work on partnership, "that if a company is incorporated by a foreign Government so that by the constitution of that company the members are rendered wholly irresponsible, or only to a limited extent responsible, for the debts and engagements of the company, the liability of the members as such would be the same in this country as in the country which created the corporation." But it was contended that the Legislature of Western Australia had a right, if it thought fit, to annex any kind of condition to the carrying on business in their own territory, and that, by the construction which should be put upon the Ordinance of 1858 , it had enacted that unless a foreign corporation, carrying on business in Western Australia, complied with this Ordinance and was registered according to its provisions, its individual members should be liable to be sued for its debts. It was stated, and properly, that the real question in the case was whether the Western Australian Legislature so enacted.

In considering that question, we may first look to the principal which was laid down by Story, ${ }^{15}$ and quoted by the Chief Justice in his summary of the argument for the Plaintiff in these words: "In the silence of any positive rule affirming or denying or restraining the operation of foreign laws, Courts of justice presume the tacit adoption of them by their own Government, unless they are repugnant to its policy or prejudicial to its interests." Therefore, we have to see whether upon the true construction of this Ordinance, the Legislature of Western Australia has said that a company incorporated in another colony or in a foreign country, not having complied with its provisions, cannot carry on business or make contracts in Western Australia by its agent without its members being liable individually for its debts or engagements.

\section{Sir Richard Couch further stated:16}

This is in accordance with a decision of their Lordships in the case of Bulkeley v. Schultz, ${ }^{17}$ where it was held that "a railway company and a partnership complete and existing in a foreign country is not within the purview of the English Joint Stock Companies Acts of 1856, 1857, so as to enable H.B. Majesty's Consular Court in Egypt to issue a sequestration against such of the members of the company as were resident within the jurisdiction of that Court, for not complying with an order of that Court to register the company as one of limited liability under the English Acts." The company there, being a complete and existing company, could not be registered as one of limited liability under the English Acts.

On the basis of the reasoning in the Bateman case, it would appear that once it is determined that the status of a drilling fund partnership will be recognized, it will also be recognized that the partnership has

\footnotetext{
it Id. at 389.

15 Referring to Conflict of Laws, (2nd ed.) s. 38.

${ }^{16}$ Id. at 391.

17 Referring to (1871) L.R. 3 P.C. 764.
} 
the right to carry on business in the particular jurisdiction unless the legislation of that jurisdiction can be construed as prohibiting it from doing so; or the fact of its carrying on business in the jurisdiction would be repugnant to that jurisdiction's policy or prejudicial to its interest. In this regard, it is submitted that the limited partnership legislation of each of the jurisdictions cannot reasonably be interpreted in such a manner that would lead to the conclusion that the legislature intended to prohibit foreign limited partnerships from carrying on business in the jurisdiction. As indicated at the outset, such legislation, because of its particular wording, would apply only to limited partnerships formed within the jurisdiction.

Secondly, based on the Bateman case, it would appear that failure to comply with the limited partnership legislation of the jurisdiction would not, in itself, be something that is repugnant to the policy of the jurisdiction or prejudicial to its interests. In this connection, it is submitted that it is necessary to look at the actual activities carried on by the partnership to determine whether such activities are repugnant to the policy of the jurisdiction or prejudicial to its interest. In the case of a drilling fund partnership, it would not be doing anything more than a limited partnership formed in the jurisdiction would be entitled to do, namely, participate in the oil and gas business, and accordingly, it is difficult to see how the proposed activities of a drilling fund partnership would be repugnant to the policy of the jurisdiction or prejudicial to its interest unless foreign ownership by itself would constitute such an activity and it would appear that to date, at least, the policy of each of the jurisdictions is not to prevent foreign ownership.

The Bateman case also indicates that if the limited partnership is recognized as being entitled to carry on business in the jurisdiction, the limited partners in the drilling fund partnership would not lose their limited liability in respect to the debts and obligations of the drilling fund partnership as a result of a failure of the partnership to comply with legislation of a jurisdiction which pertains only to limited partnerships formed within the jurisdiction.

It is the writer's view that the present limited partnership legislation of each jurisdiction does not purport to apply to a foreign limited partnership, and that where such foreign limited partnership is a separate legal entity under the laws of the jurisdiction where it was formed, it will, subject to any other restrictions hereinafter considered, be legally entitled to carry on business in the jurisdiction without exposing the limited partners thereof to general liability for the debts and obligations of the partnership. Where the foreign limited partnership is not a separate legal entity under the laws of the jurisdiction where it was formed, it is not clear whether such partnership would be recognized as being entitled to carry on business in the jurisdiction without exposing the limited partners to general liability for the debts and obligations of the partnership. Where there is some doubt as to whether the partnership will be recognized, it is suggested that, as a matter of caution, steps should be taken to comply with the limited partnership legislation of each jurisdiction even though it does not purport to apply to foreign limited partnerships.

As stated by Gower, ${ }^{18}$ it is only right that foreign companies carrying

19 Gower, Modern Company Law 673 (3rd ed. 1969). 
on business in another jurisdiction be required to make the same, or even greater disclosure, as is required with respect to companies formed in that jurisdiction. He goes on to state that it is for this reason that provisions were added to the English Companies Act to provide for the registration of foreign companies. The same type of legislation is to be found in each of the jurisdictions in respect to the registration of foreign companies. However, it would appear that to date the question of registration of foreign partnerships has not been given any real consideration, ${ }^{19}$ and it is suggested that the partnership acts of the various jurisdictions should be amended so as to provide for the registration of foreign limited partnerships in order that the same disclosure may be obtained from them as is required in respect to limited partnerships formed in the jurisdiction.

\section{OTHER STATUTORY RESTRICTIONS}

Further possible restrictions relating to the ability of foreign limited partnerships to carry on business in each of the jurisdictions are to be found in the companies acts of each of the jurisdictions. In this regard, the British Columbia Companies Act provides as follows: ${ }^{20}$

9(1) No company, association, or partnership consisting of more than twenty persons shall be formed within the Province for the purpose of carrying on or shall carry on any business that has for its object the acquisition of gain by the company, association, or partnership, or by the individual members thereof, unless it is incorporated as a company under this Act, or is formed in pursuance of some other Act of the Legislature, or, in the case of a partnership consisting of more than twenty persons but not more than thirty-five persons, the partnership is authorized by Lieutenant-Governor in Council to carry on business within the Province.

(2) A company or association formed elsewhere than in this Province, that is not duly incorporated by or under a Statute, Act, or Ordinance of the Province, State, or country where it was formed, shall not carry on business in this Province or be registered under Part VII. [Emphasis added].

It is clear from subsection 1 of Section 9 that the same applies not only to companies, associations or partnerships formed within the Province of British Columbia but also to any company, association, or partnership which desires to carry on business in the Province of British Columbia, regardless of where it was formed. Accordingly, it is the writer's view that a drilling fund partnership consisting of more than twenty persons would not be entitled to carry on business within the Province of British Columbia unless, in the case where its membership did not exceed more than 35 persons, it obtained authority from the Lieutenant-Governor in Council of the Province of British Columbia.21

Because of the use of the word "association" in subsection 2 of the above quoted Section 9, there is some question as to whether a foreign partnership consisting of even twenty members or less would be entitled to carry on business in the Province of British Columbia. However, since partnerships are specifically referred to in subsection 1 of Section 9 , it would appear that it was not intended to include partnerships within subsection 2 of Section 9 and that, therefore, the word "association" should not be construed so as to include a partnership.

19 In this regard it is noted that the Province of Nova Scotia has such legislation: see Partnership and Business Names Registration Act, R.S.N.S. 1967, c. 225; as does the State of New Hampshire: see N.H. Rev. Stat. Ann.
Ch. 305-A (1965).

20 R.S.B.C. 1960 , c. 67.

21 To the writer's knowledge certain drilling funds have obtained this authority. 
If a limited partnership were to carry on business in the Province of British Columbia in contravention of Section 9(1) of the Companies Act, it it submitted that such violation would not constitute an offence under the act because an examination of the act reveals that the act clearly spells out when a contravention thereof will constitute an offence. It does not do so in the case of a contravention of Section 9(1). Accordingly, such violation would not be met with a penalty or fine, but, based on the decisions of Northwestern Construction Company v. Young ${ }^{22}$ and Ireland v. Andrews, ${ }^{23}$ it would appear that any contracts entered into by the partnership in British Columbia would be illegal and unenforceable.

The Companies Act of the Province of Alberta ${ }^{24}$ and the Companies Ordinance of the Northwest Territiories, ${ }^{25}$ each contain a provision similar to the above quoted subsection 1 of Section 9 of the Companies Act of the Province of British Columbia, except for the provision providing for authority to be obtained from the Lieutenant-Governor in Council. However, the Partnership Act of the Province of Alberta and the Partnership Ordinance of the Northwest Territories were recently amended to provide that there may be any number of limited partners in a limited partnership. ${ }^{26}$ Nevertheless, it is not entirely clear whether a foreign limited partnership having more than twenty members would be legally entitled to carry on business in Alberta and the Northwest Territories, because it can be argued, with some merit in the writer's view, that the above mentioned amendments, like the remainder of the limited partnership legislation of such jurisdictions, apply only to limited partnerships formed under the limited partnership legislation of the jurisdiction and not to foreign limited partnerships. Accordingly, since the matter is not entirely clear, if a foreign limited partnership has more than twenty members, it would be wise to register as a limited partnership under the provisions of the Alberta and Northwest Territories limited partnership legislation.

Section 4 of the Companies Act of Saskatchewan provides as follows:27

No company, association or partnership consisting of more than twenty persons shall be formed for the purpose of carrying on any business that has for its object the acquisition of gain by the company, association or partnership, or by the individual members thereof, unless it is incorporated under this Act, or by or under some other Act of the Legislature. [Emphasis added].

The Companies Ordinance of the Yukon Territory ${ }^{28}$ contains a provision similar to the above quoted section in that it also refers to the formation of a company, association or partnership and accordingly, it is the writer's view that the section does not apply to foreign partnerships formed outside of the jurisdiction. Therefore, in Saskatchewan and the Yukon Territory, it is not necessary to be concerned about whether the drilling fund partnership is composed of more than twenty persons.

A further problem may arise in respect to the name of the drilling

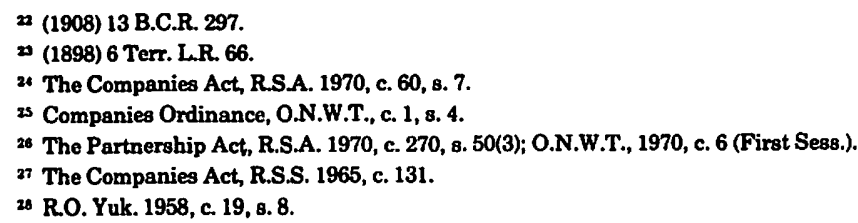


fund partnership. In this regard, Section 10 of the British Columbia Companies Act provides as follows: ${ }^{29}$

\begin{abstract}
Subject to any other Act of the Legislature, no person or persons shall trade or carry on business within the Province under any name or title of which "limited", "limited liability", or "limited, non-personal liability", or any contraction or imitation of any of those words, is or are the last word or words, unless duly incorporated with limited liability and entitled to use such.word or words, and every person so trading or carrying on business shall be liable to a fine not exceeding twenty-five dollars for every day upon which that name or title has been used.
\end{abstract}

Each of the jurisdictions has a provision in its companies act to the same effect. It has been the writer's experience that, in some instances drilling fund partnerships have, in fact, purported to use the word "limited" as the last word in their name and it is clear that such use is specifically prohibited.

\title{
E. SUMMARY
}

In conclusion, in considering the necessity of registering foreign limited partnerships in each of the jurisdictions, the following matters should be considered:

(a) whether the partnership is a legal entity under the laws where it was formed;

(b) the number of limited partners; and

(c) the name of the partnership.

Based on the answers to these questions, it can be determined whether the partnership is legally entitled to carry on business in the jurisdiction and, if so, whether it is necessary or advisable to comply with the limited partnership legislation of the particular jurisdiction.

\section{F. OWNERSHIP BY DRILLING FUND PARTNERSHIPS OF LEASES ISSUED PURSUANT TO SECTION 55 OF THE CANADA OIL AND GAS LAND REGULATIONS}

It is the writer's understanding that there are drilling fund partnerships which own interests in oil and gas exploratory permits issued by the Government of Canada and in respect to which application for an oil and gas lease may be made pursuant to Section 55 of the Canada Oil and Gas Land Regulations which reads as follows: ${ }^{30}$

55(1) Upon application to the Minister, a permitee shall be granted an oil and gas lease.

(2) An oil and gas lease shall not be granted under this section

(a) to a person unless the Minister is satisfied that he is a Canadian citizen over 21 years of age, and that he will be the beneficial owner of the interest to be granted;

(b) to a corporation incorporated outside of Canada; or

(c) to a corporation unless the Minister is satisfied

(i) that at least $50 \%$ of the issued shares of the corporation is beneficially owned by persons who are Canadian citizens, or

(ii) that the shares of the corporation are listed on a recognized Canadian stock exchange and that Canadians will have an opportunity of participating in the financing and ownership of the corporation, or

(iii) that the shares of the corporation are wholly owned by a corporation that meets the qualifications outlined in subparagraph (i) or (ii) of this paragraph.

30 Canada Oil and Gas Land Regulations, SOR/61-253, (1961) 95 Canada Gazette (Part II) 805, 6 June, 1961. 
Section 55 applies to all lands forming part of the Dominion of Canada which are owned by Her Majesty in Right of Canada except for such of those lands as are situate within the boundaries of any province of Canada.

The effect of Section 55(2) is that, while the drilling fund partnership would be entitled through the general partner to hold oil and gas exploratory permits covering lands which are subject to Section 55(2), it would appear that it would not be entitled to hold any lease which might be issued out of such permits, because the drilling fund partnership would not be a person or company entitled to be granted a lease pursuant to Section 55 .

Can it be argued that Section 55 relates only to the registered ownership of the leases issued so that the registered and legal ownership of the lease could be vested in a nominee company or person that qualified under Section 55 while the beneficial ownership of the lease would be held in trust by such nominee for the drilling fund partnership? It is submitted that such an interpretation would fly in the face of the purpose of Section 55, that purpose being, it would seem, to ensure that any leases issued are either owned beneficially by a Canadian citizen or by a Canadian corporation in which Canadians will have an opportunity to acquire shares and thereby indirectly own a beneficial interest in the lease. If Section 55 is interpreted so as to allow interests to be held in trust, that purpose is clearly defeated.

If the writer is correct in his view as stated above, then those drilling fund partnerships holding interests in permits covering lands subject to Section 55 will be required to make some alternative ownership arrangements at the time that the permit is converted to lease. In this regard, it is the writer's understanding, that it is imperative that the limited partnership own a working interest in the lands upon which oil and gas exploration is conducted in order that the limited partners will be entitled to deduct certain oil and gas exploratory expenses against their gross income. Further, where the limited partnership is conducting exploration in order to earn an interest in the permit, it is the writer's understanding that it is imperative that the limited partnership own one hundred per cent of the drilling spacing unit until such time as it has recovered out of the gross proceeds of production, after deducting base royalties, overriding royalties, net profits, interests and operating costs, the costs incurred by it in drilling and completing the earning well and any other costs related to earning an interest in the lands. If that is the case, then upon the writer's interpretation of Section 55 it would be impossible for the limited partners to deduct from their gross income the expenses incurred by them in carrying out exploration, as such partners would not be entitled to own a working interest in the leases issued out of the permits and the lands could not be produced until leases are in fact selected. One possible solution to the ownership problem is that the limited partnership could convert its working interest in the permit to a net profits interest prior to the selection of leases. It would have to be a true net profits interest in the sense that the limited partnership would not own any interest in the leases or the lands subject thereto, but rather, would simply have an interest in the profits generated from the operation thereof. This, of course, would involve the party who became the owner of the lease with the problem 
of raising funds for further development in respect to those lands subject to the leases issued, because under a true net profits situation the owner of the net profits interest would not be contributing to development costs. The writer is not aware whether, under such a net profits arrangement, the limited partners would be entitled to deduct against their gross income the expenses which they had incurred in respect to exploring the lands while in permit stage. 